\title{
ANALISIS TINDAK PIDANA PENGGUNAAN ALAT RAPID TEST ANTIGEN BEKAS OLEH OKNUM PETUGAS MEDIS KIMIA FARMA
}

\author{
Indah Wahyuni Dian Ratnasari \\ Fakultas Hukum Universitas Hasanuddin \\ Jl. Pintu Dua Unhas No. KM.10, Tamalanrea Indah, Kota Makassar, Sulawesi Selatan. 90245. \\ Telp. (0411)587219 \\ Email:wdrindah@gmail.com
}

\begin{abstract}
The RT-PCR Test or rapid antigen test is a very profitable business for health service providers. This opportunity made the medical officer of Kimia Farma at Kualanamu International Airport Medan, North Sumatra took advantage of this situation by recycling the rapid antigen test kit. Therefore, it is necessary to study these problems with the formulation of problems that related to legal regulations that have been violated in the use of used rapid antigen test kit, as well as criminal threats that can be applied to the use of used rapid antigen test kit by the medical officer of Kimia Farma. The results of the study indicate that the actions of the medical officer of Kimia Farma are unlawful acts that violate various articles in the Health Law and the Consumer Protection Law. As well as the threat of criminal articles that can be applied to the medical officer is Article 196 of the Health Law (UU Kesehatan), Article 62 paragraph (1) of the Consumer Protection Law (UUPK), and Article 63 letter a of the Consumer Protection Law (UUPK).
\end{abstract}

Keywords: Crime, Used Antigen Rapid Test Tool, Medical Officer.

\section{ABSTRAK}

Tes RT-PCR atau rapid test antigen menjadi bisnis yang sangat menguntungkan bagi penyedia jasa pelayanan kesehatan. Peluang tersebut membuat oknum petugas medis Kimia Farma di Bandara Internasional Kualanamu Kota Medan Sumatera Utara memanfaatkan keadaan tersebut dengan cara melakukan daur ulang alat rapid test antigen. Sehingga dipandang perlu untuk mengkaji permasalahan tersebut dengan rumusan masalah terkait pengaturan hukum yang dilanggar dalam penggunaan alat rapid test antigen bekas, serta ancaman pidana yang dapat diterapkan atas penggunaan alat rapid test antigen bekas oleh oknum petugas medis kimia farma. Hasil penelitian menunjukkan bahwa Tindakan oknum petugas medis kimia farma adalah tindakan melawan hukum yang melanggar berbagai ketentuan dalam UU Kesehatan dan UU Perlindungan Konsumen. Serta ancaman pasal pidana yang dapat diterapkan kepada para pelaku yakni Pasal 196 UU Kesehatan, Pasal 62 ayat (1) UUPK, dan Pasal 63 huruf a UUPK. Kata Kunci: Tindak Pidana, Alat Rapid Test Antigen Bekas, Petugas Medis.

\section{PENDAHULUAN}

Coronavirus Disease (Covid-19) secara resmi dideklarasikan sebagai "pandemi" pada tanggal 9 Maret 2020 oleh World Health Organization atau Badan Kesehatan Dunia (WHO). Istilah pandemi tidak merujuk pada keganasan dampak yang diakibatkan oleh Coronavirus Disease (Covid-19), akan tetapi merujuk pada perkembangan penyebaran
Coronavirus Disease (Covid-19) yang sangat cepat sehingga telah meluas dan menyebar secara massal di berbagai negara di dunia.

Pada umumnya Coronavirus Disease (Covid-19) menimbulkan gejala yang ringan sampai gejala yang sedang berupa batuk dan demam, dengan tingkat kesembuhan dalam rentan waktu beberapa minggu. Akan tetapi, Coronavirus Disease (Covid-19) juga dapat 
menimbulkan risiko tinggi terhadap kelompok lanjut usia dan orang dengan masalah kesehatan bertahun-tahun seperti penyakit jantung, tekanan darah tinggi, atau diabetes. ${ }^{1}$

Sebagai suatu negara hukum, menurut Scheltema unsur-unsur negara hukum rechstaat adalah: (a) kepastian hukum; (b) persamaan; (c) demokrasi; dan (d) pemerintahan yang melayani kepentingan umum. $^{2}$ Berbagai upaya terus dilakukan pemerintah dalam melindungi seluruh masyarakat dari ancaman penularan Coronavirus Disease (Covid-19).

Upaya tersebut merupakan langkah nyata dalam mewujudkan salah satu tujuan negara berdasarkan Alinea Keempat Pembukaan Undang-Undang Dasar Negara Republik Indonesia Tahun 1945 yaitu melindungi segenap bangsa Indonesia dan seluruh tumpah darah Indonesia. ${ }^{3}$

Selain itu, upaya tersebut juga merupakan amanah konstitusi berdasarkan Pasal 28H ayat (1) Undang-Undang Dasar Negara Republik Indonesia Tahun 1945 yang menentukan bahwa setiap orang berhak hidup sejahtera lahir dan batin, bertempat tingal dan mendapatkan lingkungan hidup yang baik dan sehat serta berhak memperoleh pelayanan kesehatan. ${ }^{4}$

Tujuan tersebut khususnya dalam bidang kesehatan berdasarkan Poin Menimbang huruf $b$ Undang-Undang Nomor 36 Tahun 2014 tentang Kesehatan (UU Kesehatan) yang pada intinya menyatakan bahwa kesehatan sebagai hak asasi manusia harus diwujudkan dalam bentuk pemberian berbagai pelayanan kesehatan kepada seluruh masyarakat. $^{5}$

Selain dalam bidang kesehatan, tujuan perlindungan negara terhadap ancaman Coronavirus Disease (Covid-19) juga diwujudkan dalam berbagai sektor termasuk pemulihan ekonomi nasional sebagai salah satu aspek yang sangat terdampak dengan adanya pandemi Coronavirus Disease (Covid-19), yakni Presiden menerbitkan peraturan pemerintah penganti undangundang (PERPU) yang selanjutnya disetujui oleh Dewan Perwakilan Rakyat (DPR) sehingga saat ini telah menjadi undangundang yakni Undang-Undang Nomor 2 Tahun 2020 tentang Penetapan Peraturan Pemerintah Pengganti Undang-Undang Nomor 1 Tahun 2020 tentang Kebijakan

1 Satuan Tugas Penanganan COVID-19, (__ $)$, Apa Yang Dimaksud Dengan Pandemi, diakses tanggal 26 Mei $2021 \quad$ pukul $15.00 \quad$ WITA, https://covid19.go.id/tanyajawab?search=Apa\%20yang\%20dimaksud\%20dengan\%20pandemi.

2 Fajlurrahman Jurdi, (2019), Hukum Tata Negara Indonesia, Jakarta; Kencana, Hlm. 42.

3 Yohanes Suhardin, (Juli-September 2012), Peranan Negara Dan Hukum Dalam Memberantas Kemiskinan Dengan Mewujudkan Kesejahteraan Umum, Jurnal Hukum dan Pembangunan, Vol. (__ ), No. 3, Hlm. 303.

4 M. Aris Munandar, Audyna Mayasari Muin, Hijrah Adhyanti Mirzana, (Februari 2021), Telaah Ketentuan Pidana Kekarantinaan Kesehatan Berdasarkan Undang-Undang Nomor 6 Tahun 2018 Bagi Kesehatan Notaris Dan Masyarakat Era Pandemi Covid-19, Jurnal Hukum dan Kenotariatan, Vol. 5, No. 1, Hlm. 80-81.

5 Undang-Undang Nomor 36 Tahun 2014 tentang Kesehatan. 
Keuangan Negara dan Stabilitas Sistem Keuangan Untuk Penanganan Pandemi Coronavirus Disease (Covid-19) dan/atau Dalam Rangka Menghadapi Ancaman yang Membahayakan Perekonomian Nasional dan /atau Stabilitas Sistem Keuangan Menjadi Undang-Undang (untuk selanjutnya disebut UU No. 2 Tahun 2020).

UU No. 2 Tahun 2020 lahir atas dasar implikasi pandemi Coronavirus Disease (Covid-19) telah berdampak antara lain terhadap perlambatan pertumbuhan ekonomi nasional, penurunan penerimaan negara, dan peningkatan belanja negara dan pembiayaan, sehingga diperlukan berbagai upaya Pemerintah untuk melakukan penyelamatan kesehatan dan perekonomian nasional, dengan fokus pada belanja untuk kesehatan, jaring pengaman sosial (social safety net), serta pemulihan perekonomian termasuk untuk dunia usaha dan masyarakat yang terdampak. ${ }^{6}$

Salah satu kebijakan yang dilakukan pemerintah dalam melakukan pencegahan penularan dan penyebaran Coronavirus Disease (Covid-19) dari satu daerah ke daerah lain adalah dengan menerapkan persyaratan protokol kesehatan yang ketat kepada masyarakat yang hendak melakukan perjalanan khususnya menggunakan transportasi udara. Persyaratan tersebut diatur dalam Surat Edaran Satuan Tugas Penanganan Coronavirus Disease (Covid-19) Nomor 7 Tahun 2021 tentang Perpanjangan Ketentuan Perjalanan Orang Dalam Negeri Pada Masa Pandemi Coronavirus Disease (Covid-19) yang menentukan bahwa setiap orang yang hendak melakukan perjalanan menggunakan pesawat udara wajib atau harus menunjukkan surat keterangan hasil negatif tes Rapid Test-Polymerase Chain Reaction (untuk selanjutnya disebut RT-PCR) atau hasil negatif rapid test antigen. ${ }^{7}$

Persyaratan tersebut pada dasarnya telah diberlakukan oleh pemerintah sejak tahun 2020 dengan mekanisme teknis yang semakin diperketat seiring dengan berkembangnya kasus penularan Coronavirus Disease (Covid19). Pemberlakukan RT-PCR atau rapid test antigen kepada masyarakat telah menjadi hal yang umum diketahui oleh setiap orang khususnya orang-orang yang hendak melakukan perjalanan menggunakan pesawat udara. Pemberlakuan protokol kesehatan tersebut pada dasarnya bertujuan agar seseorang yang melakukan perjalanan tidak membawa/menularkan Coronavirus Disease (Covid-19) ke daerah tujuan dan tidak

6 Undang-Undang Nomor 2 Tahun 2020 tentang Penetapan Peraturan Pemerintah Pengganti Undang-Undang Nomor 1 Tahun 2020 tentang Kebijakan Keuangan Negara Dan Stabilitas Sistem Keuangan Untuk Penanganan Pandemi Coronavirus Disease (Covid-19) dan/atau Dalam Rangka Menghadapi Ancaman yang Membahayakan Perekonomian Nasional dan/atau Stabilitas Sistem Keuangan Menjadi Undang-Undang.

7 Surat Edaran Satuan Tugas Penanganan Coronavirus Disease (Covid-19) Nomor 7 Tahun 2021 tentang Perpanjangan Ketentuan Perjalanan Orang Dalam Negeri Pada Masa Pandemi Coronavirus Disease (Covid19). 
membawa/menularkan Coronavirus Disease (Covid-19) pada saat perjalanan pulang.

Pemberlakuan RT-PCR atau rapid test antigen sebelum melakukan perjalanan menggunakan pesawat udara saat ini menjadi semakin ketat. Hal tersebut terlihat dari jangka waktu berlaku dari hasil tes tersebut yang dulunya berlaku selama 14 hari, kini berubah menjadi semakin ketat dengan ketentuan sebagai berikut: ${ }^{8}$

1. Perjalanan ke Pulau Bali:

a. Tes RT-PCR berlaku 2 × 24 jam;

b. Rapid test antigen berlaku 1 x 24 jam.

2. Perjalanan dari dan ke Pulau Jawa serta di dalam Pulau Jawa:

a. Tes RT-PCR berlaku 3 × 24 jam;

b. Rapid test antigen berlaku 2 × 24 jam.

Bahkan pemerintah juga sempat memberlakukan peraturan khusus yang berlaku pra dan pasca hari raya idul fitri tahun 2021 menjadi lebih ketat yakni RT-PCR atau rapid test antigen hanya berlaku 1 x 24 jam. Namun ketentuan ini hanya berlaku terbatas yakni dari tanggal 24 April - 24 Mei 2021.

Pengetatan aturan RT-PCR atau rapid test antigen pada perjalanan menggunakan pesawat udara tentunya berdampak pada tingkat penggunaan dan kebutuhan RT-PCR atau rapid test antigen yang semakin tinggi. Hal tersebut adalah konsekuensi atas waktu berlaku RT-PCR atau rapid test antigen yang semakin singkat. Sehingga setiap orang yang dulunya menggunakan pesawat udara dengan perjalanan pergi dan pulang hanya melakukan RT-PCR atau rapid test antigen 1 kali sebelum berangkat, karena jangka waktu yang berlaku adalah 14 hari, namun kini harus melakukan RT-PCR atau rapid test antigen pada saat perjalanan pergi dan melakukan RTPCR atau rapid test antigen lagi pada saat perjalanan pulang karena peraturan masa berlaku RT-PCR atau rapid test antigen berubah menjadi sangat singkat.

Atas kondisi tersebut, idealnya pemerintah dan petugas medis harus siap dan sigap dalam menyediakan fasilitas kesehatan untuk melakukan pemeriksaan RT-PCR atau rapid test antigen bagi masyarakat yang akan menggunakan transportasi udara. Hal tersebut demi menunjang pelayanan yang cepat agar masyarakat tidak kesulitan dan harus mengantri dengan waktu yang lama hanya untuk melakukan RT-PCR atau rapid test antigen.

Ketersedian fasilitas RT-PCR atau rapid test antigen yang mudah diakses serta kualitas pelayanan yang baik tentu akan sangat menguntungkan masyarakat, utamanya agar tidak mempersulit dan menyita banyak waktu hanya untuk memperoleh surat keterangan negatif RT-PCR atau rapid test antigen. Hal tersebut didasarkan pada fakta yang terjadi pada bulan Desember 2020 yang lalu, yakni pada saat awal pemberlakuan rapid test 
antigen masyarakat sangat kesulitan dan harus mengantri beberapa jam hanya untuk mengikuti tes RT-PCR atau rapid test antigen. ${ }^{9}$ Sehingga hal tersebut sangat menghambat aktivitas bahkan sangat merugikan masyarakat.

Kebutuhan RT-PCR atau rapid test antigen yang tinggi tentu tidak hanya dipandang dari aspek pelayanan kesehatan semata, akan tetapi juga merupakan peluang bisnis dibidang kesehatan. Biaya RT-PCR atau rapid test antigen yang cukup mahal menjadikan RT-PCR atau rapid test antigen menjadi peluang bisnis yang sangat menguntungkan bagi penyedia jasa pelayanan kesehatan.

Hal tersebut terlihat dari banyaknya penyedia jasa kesehatan yang menyediakan jasa RT-PCR atau rapid test antigen baik yang disediakan oleh pemerintah maupun oleh rumah sakit swasta, klinik swasta, laboratorium kesehatan swasta, bahkan sampai maskapai penerbangan Lion Air juga ikut menyediakan RT-PCR atau rapid test antigen khusus untuk penumpang maskapai Lion Air, Wings Air, dan Batik Air yang tergabung dalam Lion Group. ${ }^{10}$
Penyediaan fasilitas RT-PCR atau rapid test antigen pada dasarnya sangat menunjang bagi kemudahan dan kenyamanan masyarakat, namun dari aspek lain, pemerintah harus proaktif dalam melakukan kontrol dan pengawasan agar masyarakat dapat memperoleh pelayanan terbaik. Kualitas pelayanan menjadi perhatian yang paling utama dalam penyediaan jasa RT-PCR atau rapid test antigen, mengingat Coronavirus Disease (Covid-19) adalah virus yang sangat mudah untuk menular kepada orang lain.

Atas kebutuhan penyedia jasa pelayanan RT-PCR atau rapid test antigen yang semakin tinggi di Indonesia, membuat beberapa oknum memanfaatkan situasi dan kondisi tersebut untuk memperoleh keuntungan. Salah satu tindakan tersebut adalah dilakukan oleh oknum petugas medis Kimia Farma yang dengan sengaja melakukan daur ulang alat rapid test antigen, kemudian menggunakan alat rapid test antigen bekas kepada masyarakat yang melakukan tes. Kasus penggunaan alat rapid test antigen bekas tersebut terjadi di Bandara Internasional Kualanamu Kota Medan Sumatera Utara. ${ }^{11}$

9 Dewia Kania, (21 Desember 2020), Antre Rapid Test Antigen Penumpang Menumpuk Di Bandara Soekarno Hatta, Diakses pada tanggal 28 Mei 2021 pukul 13.00 WITA, https://travel.okezone.com/read/2020/12/21/406/2331329/antre-rapid-test-antigen-penumpang-menumpukdi-bandara-soekarno-hatta.

10 Syifa Nuri Khaerunnisa, Kompas.Com, (16 Januari 2021), 16 Lokas Layanan Rapid Test Antigen Dan Jadwalnya, diakses pada pukul 14.00 WITA, https://travel.kompas.com/read/2021/01/16/140200427/16lokasi-layanan-rapid-test-antigen-dari-lion-air-group-dan-jadwalnya?page=all.

11 Dewantoro, Kompas.com, (30 April 2021), Kronologi Lengkap Kasus Penggunaan Alat Rapid Test Bekas Di Bandara Kualanamu, diakses pada tanggal 27 Mei 2021 pukul 15.00 WITA, https://regional.kompas.com/read/2021/04/30/000157178/kronologi-lengkap-kasus-penggunaan-alat-rapidtest-bekas-di-bandara?page=all 
Berdasarkan informasi, bahwa "penggunaan rapid test antigen bekas telah dilakukan selama 3 bulan yakni sejak bulan Desember 2020 dengan perkiraan korban sekitar 9.000 orang dan perkiraan keuntungan sekitar $\mathrm{Rp}$. 1,8 miliar rupiah. $^{12}$

Tindakan yang dilakukan oleh oknum petugas medis kimia farma tersebut adalah bentuk pengkhianatan nyata terhadap upaya yang selama ini dilakukan oleh pemerintah bersama dengan petugas medis dan dalam berperang melawan Coronavirus Disease (Covid-19) di Indonesia. Selain itu, tindakan tersebut merupakan kejahatan yang dapat dipidana karena dapat membahayakan kesehatan dan keselamatan, bahkan nyawa para ribuan korban yang telah menggunakan alat rapid test antigen bekas tersebut.

Berdasarkan uraian permasalahan tersebut, dipandang perlu untuk mengkaji terkait pengaturan hukum yang dilanggar dalam penggunaan alat rapid test antigen bekas oleh oknum petugas medis Kimia Farma, serta ancaman pidana yang dapat diterapkan atas penggunaan alat rapid test antigen oleh oknum petugas medis Kimia Farma. Pengkajian atau pembahasan ini bertujuan untuk memahami pengaturan hukum yang dilanggar dalam penggunaan alat rapid test antigen bekas oleh oknum petugas medis Kimia Farma, serta untuk memahami ancaman pidana yang dapat diterapkan atas penggunaan alat rapid test antigen oleh oknum petugas medis Kimia Farma.

\section{PEMBAHASAN}

\section{Pengaturan Hukum Pidana Penggunaan Alat Rapid Test Antigen Bekas Oleh Oknum Petugas Medis Kimia Farma}

Menurut James Wilford Garner bahwa tujuan negara yang asli (original) atau yang utama (primary) atau yang langsung (immediate) ialah pemeliharaan perdamaian, ketertiban, keamanan, dan keadilan. Apabila negara tidak dapat memenuhi tujuan itu, maka tidak dapat dibenarkan adanya negara itu. ${ }^{13}$ Hal tersebut sejalan dengan tujuan Negara Indonesia sebagaimana yang tertuang dalam Pembukaan Undang-Undang Dasar Negara Republik Indonesia Tahun 1945 yakni: ${ }^{14}$

1. Melindungi segenap bangsa dan seluruh tumpah darah Indonesia.

2. Memajukan kesejahteraan umum dan mencerdaskan kehidupan bangsa.

3. Ikut melaksanakan ketertiban dunia yang berdasarkan kemerdekaan, perdamaian abadi, dan keadilan sosial.

Atas dasar tujuan tersebut, maka negara membuat berbagai peraturan hukum yang berfungsi untuk mewujudkan tujuannya

12 Redaksi Lokadata, (1 Mei 2021), 9 Ribu Orang Jadi Korban Tes Antigen Bekas DI Bandara Kualanamu, diakses pada tanggal 27 Mei 2021 pukul 15.00 WITA, https://lokadata.id/artikel/9-ribu-orang-jadi-korban-tesantigen-bekas-di-bandara-kualanamu,

13 Romi Librayanto, (2010), Ilmu Negara Suatu Pengantar, Makassar; Pustaka Refleksi, Hlm. 124.

14 Dahlan Thaib, Jazim Hamidi, Ni'matul Huda, (2015), Teori dan Hukum Konstitusi, Jakarta; RajaGrafindo Persada, Hlm. 87. 
termasuk Indonesia. Indonesia termasuk negara yang menjunjung tinggi kedaulatan hukum dalam melaksanakan kehidupan berbangsa dan bernegara. Hal tersebut terwujud dalam penegasan pada Konstitusi Negara Indonesia yakni Pasal 1 ayat (3) Undang-Undang Dasar Negara Republik Indonesia Tahun 1945 bahwa Negara Indonesia adalah negara hukum.

Sebagai sebuah negara hukum, maka segala aktivitas masyarakat diatur oleh hukum sebagai batasan-batasan dalam bertindak dan menegakkan hak setiap orang, termasuk dalam hal yang berkaitan dengan tindakan kejahatan atau tindak pidana. Negara mengatur secara kompleks mengenai berbagai tindakan yang dikategorikan sebagai tindak pidana, termasuk dalam hal tindakan kejahatan berupa penggunaan alat rapid test antigen bekas yang membahayakan kesehatan dan keselamatan masyarakat di tengah situasi pandemi.

Sebelum masuk kepada pembahasan terkait pengaturan hukum yang dilanggar dalam penggunaan alat rapid test antigen bekas, maka hal mendasar yang perlu diuraikan terlebih dahulu adalah terkait hukum pidana. Menurut Pompe, hukum pidana adalah keseluruhan peraturan hukum yang menentukan perbuatan-perbuatan apa yang diancam dengan pidana dan dimana pidana itu menjelma.
Hal tersebut sejalan dengan apa yang diuraikan oleh Moeljatno, namun pandangan Pompe masih bersifat umum, oleh karena itu Moeljatno dalam pandangannya memberikan definisi yang lebih kongkret bahwa hukum pidana adalah sebagian dari pada keseluruhan hukum yang berlaku di suatu negara, yang mengadakan dasar-dasar dan aturan-aturan untuk:

1. Menentukan perbuatan yang tidak boleh dilakukan, yang dilarang, dengan disertai ancaman atau sanksi (sic) berupa pidana tertentu bagi yang melanggar larangan tersebut.

2. Menentukan kapan dan dalam hal-hal apa mereka yang telah melanggar laranganlarangan itu dapat dikenakan atau dijatuhkan pidana sebagaimana yang diancamkan.

3. Menentukan dengan cara bagaimana pengenaan pidana dapat dilaksanakan apabila ada orang yang disangka telah melanggar larangan tersebut.

Jadi Moeljatno merumuskan hukum pidana materil pada butir 1 dan butir 2, sedangkan hukum pidana formil (hukum acara pidana) pada butir $3 .{ }^{15}$

Berdasarkan definisi tersebut, maka dapat dikatakan bahwa hukum pidana mengatur batasan-batasan terkait tindakantindakan setiap orang yang dikategorikan sebagai suatu tindak pidana. Adapun yang

15 A.Z. Abidin dan Andi Hamzah, (2010), Pengantar Dalam Hukum Pidana Indonesia, Jakarta; Yarsif Watampone, Hlm. 6. 
dimaksud dengan tindak pidana atau delik atau strafbaar feit menurut Simons ialah kelakuan yang diancam dengan pidana yang bersifat melawan hukum yang berhubungan dengan kesalahan dan dilakukan oleh orang yang mampu bertanggung jawab. ${ }^{16}$ Pendapat dari simons tersebut diakui sebagai definisi yang paling lengkap oleh Utrecht dan Jonkers karena meliputi:

1. Diancam dengan pidana oleh hukum;

2. Bertentangan dengan hukum;

3. Dilakukan oleh orang yang bersalah;

4. Orang itu dipandangan bertanggung jawab atas perbuatannya. ${ }^{17}$

Berdasarkan penjelasan tersebut di atas, maka dapat diuraikan terkait beberapa peraturan hukum yang dilanggar oleh oknum petugas medis kimia farma atas tindakan penggunaan alat tes rapid test antigen bekas di Bandara Internasional Kualanamu Kota Medan. Peraturan hukum yang dilanggar antara lain:

1. Undang-Undang Nomor 36 Tahun 2009 tentang Kesehatan (UU Kesehatan)

Tindakan oknum petugas medis kimia farma yang melakukan daur ulang alat rapid test antigen yang selanjutnya dipergunakan kepada masyarakat umum adalah tindakan melawan hukum, yang sangat membahayakan kesehatan dan keselamatan masyarakat, karena proses tersebut tidak memenuhi standar mutu dan kualitas alat rapid test antigen. Oleh karena itu, tindakan tersebut telah melanggar ketentuan yang diatur dalam Pasal 98 ayat (1) dan ayat (3) UndangUndang Nomor 36 Tahun 2009 tentang Kesehatan.

Pasal 98 ayat (1) Undang-Undang Nomor 36 Tahun 2009 tentang Kesehatan, ${ }^{18}$ sediaan farmasi dan alat kesehatan harus aman, berkhasiat/bermanfaat. Bermutu, dan terjangkau.

Pasal 98 ayat (3) UU Kesehatan, ${ }^{19}$ ketentuan mengenai pengadaan, penyimpanan, pengolahan, promosi, pengedaran sediaan farmasi dan alat kesehatan harus memenuhi standar mutu pelayanan farmasi yang ditetapkan dengan peraturan pemerintah.

2. Undang-Undang Nomor 8 Tahun 1999 tentang Perlindungan Konsumen (UUPK).

Tindakan oknum petugas kimia farma yang melakukan daur ulang alat rapid test antigen yang selanjutnya dipergunakan kepada masyarakat umum selaku konsumen juga telah melanggar UUPK yakni terkait hak-hak konsumen

\footnotetext{
Ibid,. Hlm. 117.

Ibid.

18 Undang-Undang Nomor 36 Tahun 2009 tentang Kesehatan.

19 Ibid.
} 
sebagaimana diatur dalam Pasal 4 huruf

a, c, dan g Undang-Undang Nomor 8

Tahun 1999 tentang Perlindungan

Konsumen.

Pasal 4 huruf a Undang-Undang Nomor 8 Tahun 1999 tentang Perlindungan Konsumen, ${ }^{20}$ hak konsumen adalah hak atas kenyamanan, Keamanan, dan Keselamatan dalam mengkonsumsi barang dan/atau jasa.

Pasal 4 huruf c Undang-Undang Nomor 8 Tahun 1999 tentang Perlindungan Konsumen, ${ }^{21}$ hak atas informasi yang benar, jelas, dan jujur mengenai kondisi dan jaminan barang dan/atau jasa.

Pasal 4 huruf g Undang-Undang Nomor 8 Tahun 1999 tentang Perlindungan Konsumen, ${ }^{22}$ hak untuk diperlakukan atau dilayani secara benar dan jujur serta tidak diskriminatif.

Selain melanggar hak konsumen, oknum petugas medis kimia farma juga telah gagal dalam memenuhi kewajibannya selaku pelaku usaha berdasarkan Pasal 7 huruf a dan $d$ Undang-Undang Nomor 8 Tahun 1999 tentang Perlindungan Konsumen.
Pasal 7 huruf a Undang-Undang Nomor 8 Tahun 1999 tentang Perlindungan Konsumen, ${ }^{23}$ kewajiban pelaku usaha adalah beritikad baik dalam melakukan kegiatan usahanya.

Pasal 7 huruf d Undang-Undang Nomor 8 Tahun 1999 tentang Perlindungan Konsumen, ${ }^{24}$ menjamin mutu barang dan/atau jasa yang diproduksi dan/atau diperdagangkan berdasarkan ketentuan standar mutu barang dan/atau jasa yang berlaku.

Selanjutnya, oknum petugas medis kimia farma juga telah melanggar larangan atau hal yang tidak boleh dilakukan oleh pelaku usaha dalam menjalankan usaha berdasarkan Pasal 8 ayat (1) huruf a, d, e, dan ayat (3) Undang-Undang Nomor 8 Tahun 1999 tentang Perlindungan Konsumen.

Pasal 8 ayat (1) huruf a UndangUndang Nomor 8 Tahun 1999 tentang Perlindungan Konsumen, ${ }^{25}$ pelaku usaha dilarang memproduksi dan/atau memperdagangkan barang dan/atau jasa yang tidak memenuhi atau tidak sesuai dengan standar yang dipersyaratkan dan ketentuan peraturan perundangundangan.

Undang-Undang Nomor 8 Tahun 1999 tentang Perlindungan Konsumen.

Ibid.

Ibid.

3 Ibid.

24 Ibid.

25 Ibid. 
Pasal 8 ayat (1) huruf d UndangUndang Nomor 8 Tahun 1999 tentang Perlindungan Konsumen, ${ }^{26}$ tidak sesuai dengan kondisi, jaminan, keistimewaan atau kemanjuran sebagaimana dinyatakan dalam label, etiket atau keterangan barang dan/atau jasa tersebut.

Pasal 8 ayat (1) huruf e UndangUndang Nomor 8 Tahun 1999 tentang Perlindungan Konsumen, ${ }^{27}$ tidak sesuai dengan mutu, tingkatan, komposisi, proses pengolahan, gaya, mode, atau penggunaan tertentu sebagaimana dinyatakan dalam label atau keterangan barang dan/atau jasa tersebut.

Pasal 8 ayat (3) Undang-Undang Nomor 8 Tahun 1999 tentang Perlindungan Konsumen, ${ }^{28}$ pelaku usaha dilarang memperdagangkan barang yang rusak, cacat atau bekas dan tercemar dengan tanpa memberikan informasi secara lengkap dan benar.

Selanjutnya, oknum petugas medis kimia farma juga telah menawarkan barang kepada konsumen dengan ketidakjujuran yakni seolah-olah alat rapid test antigen tersebut adalah baru berdasarkan Pasal 9 ayat (1) huruf b Undang-Undang Nomor 8 Tahun 1999 tentang Perlindungan Konsumen.
Pasal 9 ayat (1) huruf b UndangUndang Nomor 8 Tahun 1999 tentang Perlindungan Konsumen, ${ }^{29}$ Pelaku usaha dilarang menawarkan, memproduksikan, mengiklankan suatu barang dan/atau jasa secara tidak benar dan/atau seolah-olah barang tersebut dalam keadaan baik dan/atau baru.

Selain telah melanggar berbagai ketentuan pidana sebagaimana telah diuraikan di atas, tindakan oknum petugas medis kimia farma juga telah bertentangan dengan berbagai peraturan yang deterbitkan oleh pemerintah dalam mencegah penularan dan penyebaran serta menanggulangi dampak pandemi Coronavirus Disease (Covid-19) di Indonesia, yakni:

1. Undang-Undang Nomor 6 Tahun 2018 tentang Kekarantinaan Kesehatan;

2. Undang-Undang Nomor 2 Tahun 2020 tentang Penetapan Peraturan Pemerintah Pengganti Undang-Undang Nomor 1 Tahun 2020 tentang Kebijakan Keuangan Negara dan Stabilitas Sistem Keuangan Untuk Penanganan Pandemi Coronavirus Disease (Covid-19) dan/atau Dalam Rangka Menghadapi Ancaman yang Membahayakan Perekonomian Nasional dan/atau Stabilitas Sistem Keuangan Menjadi Undang-Undang; 
3. Peraturan Presiden Nomor 99 Tahun 2020 tentang Pengadaan Vaksin dan Pelaksanaan Vaksinasi dalam rangka Penanggulangan Pandemi Coronavirus Disease (Covid-19) sebagaimana telah beberapa kali diubah terakhir dengan Peraturan Presiden Nomor 50 Tahun 2021 tentang Perubahan Kedua atas Peraturan Presiden Nomor 99 Tahun 2020 tentang Pengadaan Vaksin dan Pelaksanaan Vaksinasi dalam rangka Penanggulangan Pandemi Coronavirus Disease (Covid-19);

4. Peraturan Menteri Kesehatan Nomor 10 Tahun 2021 tentang Pelaksanaan Vaksinasi dalam rangka Penanggulangan Pandemi Coronavirus Disease (Covid19);

5. Peraturan Menteri Kesehatan Nomor 16 Tahun 2021 tentang Pelaksanaan Pengadaan Vaksin dalam rangka Penanggulangan Pandemi Coronavirus Disease (Covid-19);

6. Peraturan Menteri Kesehatan Nomor 18 Tahun 2021 tentang Perubahan Atas Peraturan Menteri Kesehatan Nomor 10 Tahun 2021 tentang Pelaksanaan Vaksinasi Dalam Rangka Penaggulangan Pandemi Coronavirus Disease (Covid19);

7. Keputusan Menteri Kesehatan No. HK.01.07/MENKES/4641/2021 tentang Panduan Pelaksanaan Pemeriksaan, Pelacakan, Karantina, dan Isolasi Dalam
Rangka Percepatan Pencegahan Dan Pengendalian Coronavirus Disease (Covid-19);

8. Instruksi Menteri Dalam Negeri Nomor 13 Tahun 2021 tentang Perpanjangan Pemberlakuan Pembatasan Kegiatan Masyarakat Berbasis Mikro dan Mengoptimalkan Posko Penanganan Coronavirus Disease (Covid-19) di Tingkat Desa dan Kelurahan Untuk Pengendalian Penyebaran Coronavirus Disease (Covid-19);

9. Surat Edaran Satuan Tugas Penanganan Coronavirus Disease (Covid-19) Nomor 7 Tahun 2021 tentang Perpanjangan Ketentuan Perjalanan Orang Dalam Negeri Pada Masa Pandemi Coronavirus Disease (Covid-19).

Serta beberapa ketentuan lainnya yang diterbitkan pemerintah dalam mencegah penularan serta menanggulangi dampak Pandemi Coronavirus Disease (Covid-19).

Tindakan oknum petugas medis kimia farma juga telah melakukan pengkhianatan terhadap berbagai upaya dan usaha yang telah dilakukan demi membebaskan Indonesia dari Pandemi Coronavirus Disease (Covid-19) oleh:

1. Petugas medis yang telah berjuang menyembuhkan pasien yang terinveksi Coronavirus Disease (Covid-19);

2. Pemerintah yang telah bekerja dari segala aspek khususnya pelayanan publik demi memberikan pelayanan terbaik kepada 
masyarakat baik yang terdampak Coronavirus Disease (Covid-19) secara langsung maupun dalam memitigasi resiko masyarakat yang belum terkena Coronavirus Disease (Covid-19);

3. Aparat Kepolisian, Tentara Nasional Indonesia, Dinas Perhubungan, dan berbagai instansi yang ditugaskan untuk menegakkan peraturan penerapan protokol kesehatan di lingkungan masyarakat;

4. Masyarakat yang telah berupaya menerapakan protokol kesehatan dengan mengikuti berbagai anjuran dari pemerintah dan tenaga kesehatan.

Ancaman Pidana yang Dapat Diterapkan Atas Penggunaan Alat Rapid Test Antigen Oleh Oknum Petugas Medis Kimia Farma

Penerapan suatu pasal atas tindak pidana harus memperhatikan beberapa unsur yang salah satunya adalah unsur kesengajaan dalam tindakan tersebut. Menurut Moeljatno, bahwa kesengajaan adalah pengetahuan, yaitu adanya hubungan antara pikiran atau intelek terdakwa dengan perbuatan yang dilakukan, maka sesungguhnya kesengajaan hanya terdiri atas dua corak, yaitu sengaja sebagai kepastian dan sengaja sebagai kemungkinan. ${ }^{30}$ Unsur kesengajaan menjadi salah faktor yang menentukan berat ringannya suatu penerapan pidana yang akan dijatuhkan kepada pelaku.
Selain unsur kesengajaan, tindak pidana yang dapat dijatuhkan pidana harus memenuhi unsur melawan hukum. Menurut Pompe, melawan hukum terbagi atas 2 (dua) yakni melawan hukum formil dan melawan hukum materil. Melawan hukum secara formil diartikan bertentangan dengan undangundang, apabila suatu perbuatan telah mencocoki rumusan delik, maka biasanya dikatakan melawan hukum secara formil. Sedangkan melawan hukum materil harus berarti hanya dalam arti negatif artinya kalau tidak ada melawan hukum materil maka merupakan dasar pembenaran. ${ }^{31}$

Pada dasarnya penerapan unsur tersebut di atas bertujuan untuk mewujudkan tujuan hukum baik kepada korban maupun kepada pelaku. Perwujudan tujuan hukum yang ideal menurut penulis adalah menggunakan teori ajaran prioritas yang kasuistis yang bermakna bahwa adakalanya dalam suatu kasus, keadilan yang lebih diprioritaskan ketimbang kemanfaatan dan kepastian, tetapi adakalanya tidak mesti demikian, mungkin untuk kasuskasus lain justru kemanfaatanlah yang diprioritaskan, mungkin juga kepastian yang harus diprioritaskan. ${ }^{32}$

$$
\text { Berdasarkan kronologis kasus }
$$
penggunaan alat rapid test antigen bekas oleh oknum petugas medis kimia farma, maka hal tersebut telah memenuhi unsur kesengajaan,

\footnotetext{
30 A. Zainal Abidin Farid, (2014), Hukum Pidana 1, Jakarta; Sinar Grafika, Hlm. 295.

31 Andi Hamzah, (2014), Asas-Asas Hukum Pidana Edisi Revisi, Jakarta; Rineka Cipta, Hlm. 140-141.

32 Achmad Ali, (2015), Menguak Tabir Hukum Edisi Kedua, Jakarta; Prenadamedia Group, Hlm. 100.
} 
karena tindakan tersebut dilakukan secara terencana dan sistematis, selain itu juga telah memenuhi unsur melawan hukum karena tindakan tersebut telah melanggar ketentuan dalam beberapa pasal dalam Undang-Undang Nomor 36 Tahun 2009 tentang Kesehatan dan Undang-Undang Nomor 8 Tahun 1999 tentang Perlindungan Konsumen. Atas tindakan tersebut terdapat beberapa pasal yang dapat diterapkan antara lain:

1. Pasal 196 Undang-Undang Nomor 36 Tahun 2009 tentang Kesehatan

Tindak pidana yang dilakukan oleh oknum petugas medis kimia farma yakni dengan cara mendaur ulang alat rapid test antigen, kemudian mempergunakan dalam pelayanan rapid test antigen kepada masyarakat telah membahayakan kesehatan dan keselamatan masyarakat, bahkan rapid test antigen bekas telah dipergunakan kepada sekitar 9.000 orang. Oleh karena itu, berdasarkan uraian sebelumnya maka oknum petugas medis kimia farma telah melanggar ketentuan terkait pengadaan, pengelolahan, dan peredaran hingga penggunaan standar mutu dan keamanan sediaan farmasi dan alat kesehatan yang diberikan kepada masyarakat. Oleh karena itu secara terang dan jelas bahwa oknum petugas medis kimia farma telah melanggar ketentuan dalam Pasal 98 ayat (1) dan ayat (3)
Undang-Undang Nomor 36 Tahun 2009 tentang Kesehatan.

Atas tindakan pelanggaran tersebut, maka oknum petugas medis kimia farma yang telah mendaur ulang alat rapid test antigen, kemudian mempergunakan dalam pelayanan rapid test antigen kepada masyarakat patut untuk di pidana. Adapun ancaman pasal pidana yang dapat diterapkan kepada para pelaku adalah pidana penjara berdasarkan Pasal 196 Undang-Undang Nomor 36 Tahun 2009 tentang Kesehatan.

Pasal 196 Undang-Undang Nomor 36 Tahun 2009 tentang Kesehatan, ${ }^{33}$ Setiap orang yang dengan sengaja memproduksi atau mengedarkan sediaan farmasi dan/atau alat kesehatan yang tidak memenuhi standar dan/atau persyaratan keamanan, khasiat atau kemanfaatan dan mutu sebagaimana dimaksud dalam Pasal 98 ayat (2) dan ayat (3) dipidana penjara paling lama 10 (sepuluh) tahun dan denda paling banyak Rp. 1.000.000.000,00 (satu miliar rupiah)."

2. Pasal 62 ayat (1) Undang-Undang Nomor 8 Tahun 1999 tentang Perlindungan Konsumen.

Tindakan yang dilakukan oleh oknum petugas medis kimia farma dengan cara mendaur ulang alat rapid test

33 Undang-Undang Nomor 36 Tahun 2009 tentang Kesehatan. 
antigen, kemudian mempergunakan dalam pelayanan rapid test antigen kepada masyarakat selaku konsumen adalah bentuk pelanggaran yang sangat berat, karena telah merugikan konsumen secara materil dengan menggunakan alat yang tidak baru, serta membahayakan kesehatan dan kamanan konsumen karena terancam akibat potensi penularan Coronavirus Disease (Covid-19), apalagi disaat kondisi pandemi seperti ini. Oleh karena itu, berdasarkan uraian sebelumnya maka para pelaku, telah melanggar beberapa ketentuan dalam Undang-Undang Nomor 8 Tahun 1999 tentang Perlindungan Konsumen yakni:

a. Pasal 4 huruf a, c, dan g UndangUndang Nomor 8 Tahun 1999 tentang Perlindungan Konsumen, terkait hak konsumen atas keamanan, keselamatan, informasi yang benar, pelayanan benar dan jujur atas pelayanan kesehatan yang diperoleh.

b. Pasal 7 huruf a dan d Undang-Undang Nomor 8 Tahun 1999 tentang Perlindungan Konsumen, terkait kewajiban pelaku usaha untuk beritikad baik dan menjamin mutu barang sesuai dengan standar yang berlaku.

c. Pasal 8 ayat (1) huruf a, d, dan e Undang-Undang Nomor 8 Tahun 1999 tentang Perlindungan Konsumen, terkait larangan memperoduksi dan/atau memperdagangkan barang yang tidak memenuhi standar, tidak sesuai dengan kondisi, dan tidak sesuai dengan mutu.

d. Pasal 8 ayat (3) Undang-Undang Nomor 8 Tahun 1999 tentang Perlindungan Konsumen, terkait larangan memperdagangkan barang bekas tanpa memberikan informasi secara lengkap dan benar.

e. Pasal 9 ayat (1) huruf b UndangUndang Nomor 8 Tahun 1999 tentang Perlindungan Konsumen, terkait larangan menawarkan, memproduksikan, mengiklankan barang secara tidak benar dan/atau seolah-olah barang tersebut dalam keadaan baik dan/atau baru.

Berdasarkan pelanggaranpelanggaran terhadap beberapa pasal dalam Undang-Undang Nomor 8 Tahun 1999 tentang Perlindungan Konsumen yang berkaitan dengan hak konsumen, kewajiban pelaku usaha, serta laranganlarangan terhadap pelaku usaha, maka oknum petugas medis kimia farma patut untuk dipidana dengan menggunakan Pasal 62 ayat (1) Undang-Undang Nomor 8 Tahun 1999 tentang Perlindungan Konsumen.

Pasal 62 ayat (1) Undang-Undang Nomor 8 Tahun 1999 tentang Perlindungan Konsumen, pelaku usaha 
yang melanggar ketentuan sebagaimana dimaksud dalam Pasal 8, Pasal 9, Pasal 10, Pasal 13 ayat (2), Pasal 15, Pasal 17 ayat (1) huruf a, huruf b, huruf $c$, huruf e, ayat (2) dan Pasal 18 dipidana dengan pidana penjara paling lama 5 (lima tahun atau pidana denda paling banyak $\mathrm{Rp}$ 2.000.000.000,00 (dua miliar rupiah)."

Selain itu, hasil atau keuntungan atas tindak pidana yang diperoleh oleh pelaku juga dapat diterapkan sanksi tambahan, yakni perampasan barang tertntu berdasarkan Pasal 63 huruf (a) Undang-Undang Nomor 8 Tahun 1999 tentang Perlindungan Konsumen.

Pasal 63 huruf a Undang-Undang Nomor 8 Tahun 1999 tentang Perlindungan Konsumen, terhadap sanksi pidana sebagaimana dimaksud dalam Pasal 62, dapat dijatuhkan hukuman tambahan berupa perampasan barang tertentu."

Adapun barang tertentu yang dimaksud dalam pasal ini dapat berupa peralatan yang digunakan dalam mendaur ulang alat rapid test antigen. Selain itu, juga dapat berupa hasil atau keuntungan tindak pidana berupa uang ataupun dalam bentuk lain yang telah diperoleh pelaku selama menjalankan tindak pidana tersebut.

Ancaman pidana sebagaimana pasal tersebut di atas, hukumannya akan cenderung lebih berat dengan ancaman pidana maksimal, dikarenakan situasi dan kondisi pandemi Coronavirus Disease (Covid-19) yang merupakan kondisi darurat yang terjadi hampir di seluruh negara di dunia. Kecenderungan tersebut dapat diterapkan oleh Jaksa Penuntut Umum dalam tuntutannya dengan cara menerapkan pasal berlapis atau dikenal dengan istilah Concursus/ Samenloop atau perbarengan tindak pidana.

Dalam hal ini oknum petugas medis kimia farma telah melakukan daur ulang alat rapid test antigen sehingga melanggar Undang-Undang Nomor 8 Tahun 1999 tentang Perlindungan Konsumen dan melanggar Undang-Undang Nomor 36 Tahun 2009 tentang Kesehatan karena membahayakan kesehatan masyarakat terlebih lagi ditengah pandemi Coronavirus Disease (Covid-19).

Selain itu penerapan pidana lebih berat juga dapat dilakukan oleh Hakim dalam memutus perkara yakni dalam kedudukannya dapat memutus terdakwa dengan ancaman pidana maksimal, dengan mempertimbangkan akibat buruk yang dilakukan oleh tindakan oknum petugas medis yang seharusnya menjadi pelayan kesehatan untuk masyarakat namun justru membahayakan masyarakat demi keuntungan pribadi.

\section{KESIMPULAN}

Tindakan oknum petugas medis kimia farma yang melakukan daur ulang alat rapid test antigen yang selanjutnya dipergunakan 
kepada masyarakat umum adalah tindakan melawan hukum yang melanggar berbagai ketentuan yakni:

1. Pasal 98 ayat (1) dan ayat (3) UndangUndang Nomor 36 Tahun 2009 tentang Kesehatan terkait pengadaan, pengelolahan, dan peredaran hingga penggunaan standar mutu dan keamanan sediaan farmasi dan alat kesehatan yang diberikan kepada masyarakat;

2. Pasal 4 huruf (a), (c), dan (g) UndangUndang Nomor 8 Tahun 1999 tentang Perlindungan Konsumen terkait hak konsumen atas keamanan, keselamatan, informasi yang benar, pelayanan benar dan jujur atas pelayanan kesehatan yang diperoleh;

3. Pasal 7 huruf (a) dan (d) Undang-Undang Nomor 8 Tahun 1999 tentang Perlindungan Konsumen terkait Kewajiban pelaku usaha untuk beritikad baik dan menjamin mutu barang sesuai dengan standar yang berlaku;

4. Pasal 8 ayat (1) huruf a, d, dan e UndangUndang Nomor 8 Tahun 1999 tentang Perlindungan Konsumen terkait larangan memperoduksi dan/atau memperdagangkan barang yang tidak memenuhi standar, tidak sesuai dengan kondisi, dan tidak sesuai dengan mutu;

5. Pasal 8 ayat (3) Undang-Undang Nomor 8 Tahun 1999 tentang Perlindungan Konsumen terkait larangan memperdagangkan barang bekas tanpa memberikan informasi secara lengkap dan benar;

6. Pasal 9 ayat (1) huruf b Undang-Undang Nomor 8 Tahun 1999 tentang Perlindungan Konsumen terkait larangan menawarkan, memproduksikan, mengiklankan barang secara tidak benar dan/atau seolah-olah barang tersebut dalam keadaan baik dan/atau baru.

Atas tindakan pelanggaran tersebut, maka oknum petugas medis kimia farma yang telah mendaur ulang alat rapid test antigen, kemudian mempergunakan dalam pelayanan rapid test antigen kepada masyarakat patut untuk dipidana. Adapun ancaman pasal pidana yang dapat diterapkan kepada para pelaku yakni:

1. Pasal 196 Undang Nomor 36 Tahun 2009 tentang Kesehatan;

2. Pasal 62 ayat (1) Undang-Undang Nomor 8 Tahun 1999 tentang Perlindungan Konsumen;

3. Pasal 63 huruf a Undang-Undang Nomor 8 Tahun 1999 tentang Perlindungan Konsumen.

\section{SARAN}

Adapun saran yang direkomendasikan penulis dalam permasalahan ini adalah:

1. Pemerintah harus berkoordinasi dengan baik dengan penyedia jasa pelayanan RTPCR atau rapid test antigen agar tidak terjadi hal-hal yang merugikan dan membahayakan kesehatan masyarakat selaku konsumen. 
2. Masyarakat

dan

organisasi kemasyarakatan harus proaktif untuk melaporkan apabila terdapat hal-hal yang mencurigkan terkait pelaksanaan layanan RT-PCR atau rapid test antigen.

\section{DAFTAR PUSTAKA}

\section{Peraturan Perundang-Undangan}

Undang-Undang Nomor 8 Tahun 1999 tentang Perlindungan Konsumen.

Undang-Undang Nomor 36 Tahun 2009 tentang Kesehatan.

Surat Edaran Satuan Tugas Pengendalian Coronavirus Disease (Covid-19) Nomor 7 Tahun 2021 tentang Perpanjangan Ketentuan Perjalanan Orang Dalam Negeri Pada Masa Pandemi Coronavirus Disease (Covid19).

\section{Buku}

A. Zainal Abidin Farid, (2014), Hukum Pidana 1, Jakarta; Sinar Grafika.

A.Z. Abidin dan Andi Hamzah, (2010), Pengantar Dalam Hukum Pidana Indonesia, Jakarta; Yarsif Watampone.

Achmad Ali, (2015), Menguak Tabir Hukum Edisi Kedua, Jakarta; Prenadamedia Group.

Andi Hamzah, (2014), Asas-Asas Hukum Pidana Edisi Revisi, Jakarta; Rineka Cipta.

Dahlan Thaib, Jazim Hamidi, Ni'matul Huda, (2015), Teori dan Hukum Konstitusi, Jakarta; RajaGrafindo Persada.

Fajlurrahman Jurdi, (2019), Hukum Tata Negara Indonesia, Jakarta; Kencana.

Romi Librayanto, (2010), Ilmu Negara Suatu Pengantar, Makassar; Pustaka Refleksi.

\section{Jurnal}

M. Aris Munandar, Audyna Mayasari Muin, Hijrah Adhyanti Mirzana, (Februari
2021), Telaah Ketentuan Pidana Kekarantinaan Kesehatan Berdasarkan Undang-Undang Nomor 6 Tahun 2018 Bagi Kesehatan Notaris Dan Masyarakat Era Pandemi Covid-19, Jurnal Hukum dan Kenotariatan, Vol. 5, No. 1.

Yohanes Suhardin, (Juli-September 2012), Peranan Negara Dan Hukum Dalam Memberantas Kemiskinan Dengan Mewujudkan Kesejahteraan Umum, Jurnal Hukum dan Pembangunan, Vol. (_), No. 3.

\section{Internet}

Dewantoro, (30 April 2021), Kronologi Lengkap Kasus Penggunaan Alat Rapid Test Bekas Di Bandara Kualanamu, diakses pada tanggal 27 Mei 2021 pukul 15.00 WITA, Kompas.com, https://regional.kompas.com/read/2021/ 04/30/000157178/kronologi-lengkapkasus-penggunaan-alat-rapid-testbekas-di-bandara?page $=$ all .

Dewia Kania, (21 Desember 2020), Antre Rapid Test Antigen Penumpang Menumpuk Di Bandara Soekarno Hatta, diakses pada tanggal 28 Mei 2021 pukul 13.00 WITA, Okezone.com, https://travel.okezone.com/read/2020/1 2/21/406/2331329/antre-rapid-testantigen-penumpang-menumpuk-dibandara-soekarno-hatta.

Redaksi Lokadata, (1 Mei 2021), 9 Ribu Orang Jadi Korban Tes Antigen Bekas DI Bandara Kualanamu, diakses pada tanggal 27 Mei 2021 pukul 15.00 WITA, Lokadata.id, https://lokadata.id/artikel/9-ribu-orangjadi-korban-tes-antigen-bekas-dibandara-kualanamu.

Satuan Tugas Penanganan COVID-19, (__ $)$, Apa Yang Dimaksud Dengan Pandemi, diakses tanggal 26 Mei 2021 pukul 15.00 WITA, Covid.go.id, https://covid19.go.id/tanyajawab?search=Apa\%20yang\%20dimak sud $\% 20$ dengan $\% 20$ pandemi. 
240 Yurispruden Volume 4, Nomor 2, Juni 2021, Halaman 223 - 240

Syifa Nuri Khaerunnisa, (16 Januari 2021), 16 Lokas Layanan Rapid Test Antigen Dan Jadwalnya, diakses pada pukul 14.00 WITA, https://ravel.kompas.com/read/2021/01 /16/140200427/16-lokasi-layananrapid-test-antigen-dari-lion-air-groupdan-jadwalnya?page=all, . 